\title{
New Apparatus and Experimental Setup for Long-Term Swelling Tests on Sulphatic Claystones
}

\section{Journal Article}

\section{Author(s):}

Pimentel, Erich; Anagnostou, Georg

Publication date:

2013

\section{Permanent link:}

https://doi.org/10.3929/ethz-b-000070389

\section{Rights / license:}

In Copyright - Non-Commercial Use Permitted

\section{Originally published in:}

Rock Mechanics and Rock Engineering 46(6), https://doi.org/10.1007/s00603-013-0396-5 


\title{
New Apparatus and Experimental Setup for Long-Term Swelling Tests on Sulphatic Claystones
}

\author{
Erich Pimentel • Georg Anagnostou
}

Received: 24 July 2012/Accepted: 4 March 2013/Published online: 31 March 2013

(C) Springer-Verlag Wien 2013

\begin{abstract}
An apparatus and experimental setup were developed to carry out a series of extremely slow and longlasting swelling, creep or chemo-mechanics tests simultaneously. The equipment was designed specifically for investigating the behaviour of sulphatic claystones. The tests will take at least $10-15$ years to complete and will provide unprecedented information about the so-called swelling law, i.e. the relationship between swelling strain and swelling stress. The swelling law is very important for designing tunnels in swelling rock. Our knowledge of the swelling law, however, is only sufficiently reliable with respect to claystones without anhydrite (e.g. marls, opalinus clay). The swelling law for sulphatic claystones remains unknown, even in qualitative terms. This is due to the underlying physico-chemical mechanisms, which are fundamentally different from those of purely argillaceous rocks. Another reason is the extremely long duration of the swelling process of clay-sulphate rocks, which makes systematic field or laboratory investigations very difficult. In order to close this knowledge gap, a series of 25 longterm simultaneous swelling tests has been started.
\end{abstract}

Keywords Swelling - Laboratory test .

Sulphatic claystone

$\begin{array}{ll}\text { List of Symbols } \\ F & \text { Repulsive force between clay platelets } \\ H & \text { Height of sample } \\ p & \text { Swelling pressure } \\ p_{\max } & \text { Maximum swelling pressure }\end{array}$

E. Pimentel $(\varangle) \cdot$ G. Anagnostou ETH Zurich, Zurich, Switzerland e-mail: erich.pimentel@igt.baug.ethz.ch $t \quad$ Time

$u \quad$ Tunnel invert heave

Greek Symbols

$\delta \quad$ Distance between clay platelets

$\Delta H \quad$ Change in height of the sample

$\Delta p \quad$ Support pressure

$\Delta u \quad$ Tunnel invert heave

$\varepsilon_{\text {swell }} \quad$ Swelling strain

$\sigma_{\mathrm{ax}} \quad$ Axial stress

\section{Introduction}

Swelling is a rock-water interaction phenomenon. The incorporation of water into the rock structure leads to a volume increase, which is often observed in the field as a heave of the tunnel invert. In the presence of a lining, a socalled "swelling pressure" develops, which can be high enough to impair the structural safety or serviceability of the lining.

Depending on the mineralogical composition of the rock, different mechanisms can (alone or combined) lead to swelling (Madsen and Müller-Vonmoos 1989; International Society for Rock Mechanics, ISRM 1994): the water uptake by argillaceous rocks is due to negative pore pressures and represents a purely physical process ("mechanical swelling" or "inverse consolidation"). In the so-called "osmotic swelling", water dipoles and ions are incorporated in the diffuse double layer around the clay platelets due to electrostatic interactions between them. Osmotic swelling is observed in argillaceous rocks such as claystones with relatively high content of so-called swelling minerals, e.g. smectite. Intracrystalline swelling occurs when water dipoles and ions are incorporated in the clay platelets or in the first layers of water dipoles around the 
clay platelets. This type of swelling is observed in highly compacted dry bentonite. Further water intake occurs via the diffuse double layer (osmotic swelling). Chemical swelling is associated with chemical reactions such as the anhydrite-gypsum transformation or the oxidation of pyrite in the Jurassic Posidonia Shale in South Germany (Pimentel 2003a). The growth of gypsum crystals was observed, e.g. in the sulphatic claystones of the triassic Gypsum Keuper formation (Northwestern Switzerland, Southwestern Germany) or in the tertiary Lilla claystone of the Lower Ebro Basin in Spain (Alonso et al. 2005). The swelling of the sulphatic claystones is probably due to the combined effect of gypsum growth and water uptake by the clay matrix.

Overviews of tunnelling experience in swelling rocks can be found in Einstein (1996) and Amstad and Kovári (2001). Damage induced by anhydrite swelling has been observed in several tunnels in Germany, Switzerland and Spain.

The setbacks experienced again and again in tunnels crossing sulphatic claystones are partially due to our limited knowledge about their macroscopic behaviour and about the underlying mechanisms. The latter involve chemical reaction and transport processes, as well as interactions between the sulphate and the clay matrix. Important questions concerning the influence of the clay matrix, the transport processes and the hydraulic boundary conditions are still unresolved (Anagnostou et al. 2010). Particularly unsatisfactory from a tunnel design point of view is the lack of knowledge about the relationship between swelling strain and swelling pressure in sulphatic claystones.

For purely argillaceous rocks, the "semi-logarithmic swelling law" of Grob (1972) is widely accepted; it has been confirmed by several laboratory investigations with oedometer tests, i.e. under one-dimensional swelling conditions. Figure 1 shows the basic swelling behaviour of argillaceous rocks at three different scales, namely, at the clay particle scale (Fig. 1a), at the laboratory scale (Fig. 1b) and at the tunnel scale (Fig. 1c). In oedometer tests, the axial strain or stress that develops upon watering the specimen is measured, with a stiff ring completely preventing its radial expansion. The test results show that there is a maximum axial stress $p_{\max }$, above which swelling does not occur. The strain developing at lower stresses depends linearly on the logarithm of the stress (Fig. 1b). This behaviour is a macroscopic manifestation of the electro-static interactions between clay platelets and pore water. More specifically, the semi-logarithmic swelling law can be explained on the basis of the DLVO theory (van Olphen 1963; Madsen 1976), which deals with the repulsive force between two clay platelets with overlapping diffuse double layers of water molecules around them
(Fig. 1a). As pointed out by Kovári et al. (1988), the highly non-linear relationship between swelling strain and axial stress observed in oedometer tests suggests that a similar relationship must exist between the tunnel invert heave and the swelling pressure in situ (Fig. 1c). This is important for the conceptual structural design of the tunnel lining, because it means that a relatively low support pressure $\Delta p$ might reduce the tunnel invert heave considerably or, vice versa, that a considerable reduction of the lining loading can be achieved by allowing a relatively small amount of invert heave $\Delta u$ to occur. The swelling law is, thus, essential to structural concepts. The latter can be grouped under "resistance principle" and "yielding principle" (Kovári et al. 1988). The resistance principle means a very stiff support, which is sufficiently strong to sustain the swelling pressure developing in the prevention of invert heave (point $\mathrm{A}$ in Fig. 1c). The yielding principle, on the other hand, makes use of the observation that the loading decreases if deformation is allowed to occur (point $\mathrm{B}$ in Fig. 1c). The structural detailing of the tunnel support has to ensure that the heave occurs without impairing the serviceability of the tunnel. This can be achieved by installing special support components in the form of compressible layers, highly deformable concrete elements or sliding anchors (Kovári and Chiaverio 2007).

Which structural concept is more adequate in a given situation depends, of course, on the project conditions (such as depth of cover, possibility of carrying out maintenance and repair work during operation etc.; cf. Anagnostou 2007) but also on the swelling law. The semilogarithmic swelling law is, however, theoretically and empirically founded only on purely argillaceous rocks. For sulphatic claystones, uncertainties persist in this respect (Sect. 2). The available observations are only sparse and they indicate that the assumption of a strong non-linearity between swelling stress and long-term swelling strain may be incorrect for sulphatic claystones. In order to improve our knowledge of the behaviour of these rocks, a long-term laboratory test programme has been initiated at the ETH. Section 3 presents the design of the apparatus and the experimental setup developed specifically for this purpose, while Sects. 4 and 5 deal with the test materials and first results, respectively.

\section{On the Swelling Behaviour of Sulphatic Claystones}

\subsection{The Relationship Between Swelling Stress and Swelling Strain}

The behaviour of sulphatic claystones differs considerably from that of other claystones with respect to the time 
(a)

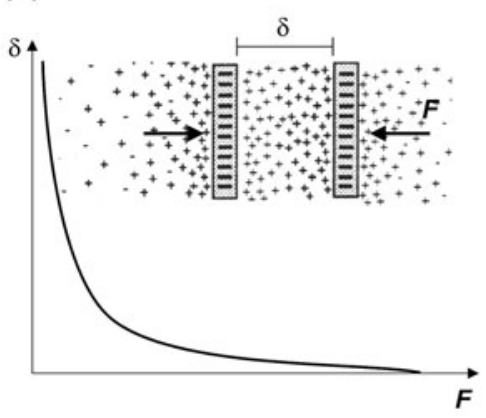

(b)



(c)



Fig. 1 a Theoretical relationship between the repulsive force $F$ and the distance $\delta$ between the clay platelets according to the DLVO theory (Madsen and Müller-Vonmoos 1989). b Macroscopic behaviour of argillaceous rock in oedometer tests (relationship between

development and magnitude of the swelling strain and stress. More specifically, it is observed in field and laboratory tests that the duration of the swelling process is generally longer for sulphatic claystones than for purely argillaceous rocks. Furthermore, both the pressure needed to prevent swelling and the strain developing under low stresses are considerably higher in the case of sulphatic claystones. In laboratory tests with purely argillaceous rocks, the duration of a single load stage amounts often to less than 2 weeks, and the maximum swelling pressure and strain are, in general, lower than $2 \mathrm{MPa}$ and $10 \%$, respectively (Madsen and Müller-Vonmoos 1989). These values can be considerably higher for sulphatic claystones: swelling strains of more than $30 \%$ and swelling pressures of $8 \mathrm{MPa}$ have been measured in oedometer tests without reaching a steady state, while the duration of one load stage may take years (Pimentel 2003b).

As a consequence of the long duration of the swelling process, almost no systematic long-term observations have been made. Most of the tests with specimens containing anhydrite were performed for determining the maximum swelling stress under oedometric conditions, i.e. the axial stress developing when preventing swelling strain completely (see, e.g. Huder and Amberg 1970; Madsen and Nüesch 1990; Flückiger et al. 1994; Nüesch et al. 1995; Vögtli and Jordan 1996; Ko et al. 1997). Therefore, they do not provide information about the relationship between swelling stress and swelling strain. There is only one laboratory test series and only one field test which are somehow useful in this respect, but neither the field tests nor the laboratory tests have yet reached completion, about 20 years after their commencement. The laboratory tests were performed on samples from the Freudenstein railway tunnel in Southwest Germany (Pimentel 2003b; see Sect. 2.2 below). This tunnel was constructed in the period 1987-1991 and crosses the Gypsum Keuper formation. In addition to the laboratory test programme, field tests were swelling strain $\varepsilon_{\text {swell }}$ and swelling pressure $p$, after Grob 1972). c Relationship between tunnel invert heave $u$ and support pressure $p$, after Kovári et al. (1988)

performed in an adit specially constructed for this purpose (Kovári et al. 1986; see Sect. 2.3 below).

\subsection{Laboratory Tests from the Freudenstein Tunnel}

The laboratory tests were run under oedometric conditions with an apparatus that allowed either load- or deformationcontrolled swelling tests (see Sect. 3). The initial aim of the tests was to check whether the swelling stress that develops under deformation constraint is lower than the load of $1 \mathrm{MPa}$, which was adopted for the design of a lining according to the resistance principle. The measured swelling stress exceeded the lining design load before long (within a few months after the test began) and reached the nominal load of the cell ( $4 \mathrm{MPa})$ after about 2 years. The increasing swelling stress necessitated several revisions of the design of the final lining of the tunnel. Finally, the initial structural concept was abandoned in favour of a lining according to the yielding principle. For the design of the deformable lining system, it was necessary to estimate the magnitude of the invert heave, which must occur so that the swelling pressure does not exceed the specified design load (Kovári et al. 1988). Consequently, the aim of the laboratory tests has been changed so that the swelling strain was to be determined from then on (Kirschke 1987). In order to measure higher stresses, several load cells were replaced by new ones that enable measurements of swelling stresses of up to $8 \mathrm{MPa}$. However, changing the load cells was impossible without impairing the test conditions by unloading and reloading the samples.

Figure 2 shows the time history of one test (Pimentel 2003b). As explained above, expansion was constrained during the first 3.3 years (test period A in Fig. 2). The swelling pressure reached the nominal load of the apparatus (more than $4 \mathrm{MPa}$ ), thus, necessitating several unloadings, which caused little deformation (the material was very stiff). After this period, the load was kept constant at 
$0.5 \mathrm{MPa}$ (test period B in Fig. 2). As a consequence, a swelling strain of about $30 \%$ developed in about 5.1 years. In the subsequent 6-year period, during which expansion was completely constrained, the swelling pressure increased to $4 \mathrm{MPa}$ again (test period $\mathrm{C}$ in Fig. 2). During the next test period (test period D in Fig. 2), the load was controlled and a relatively slow swelling rate was observed. In the last test period (test period E in Fig. 2), the deformation was constrained. The sample developed a considerable swelling pressure even after the occurrence of very large deformations.

As indicated above, in spite of the long test duration (several years), most of the loading steps produced no final state, i.e. no equilibrium. Depending on the imposed boundary conditions, these loading steps show a monotonic increase of either stress or strain over time, but with a decreasing rate. This behaviour can be described for most of the loading stages empirically with an asymptotic function. In order to gain as much information as possible from these uncompleted tests, Pimentel (2007) estimated the final values of the different loading stages by means of
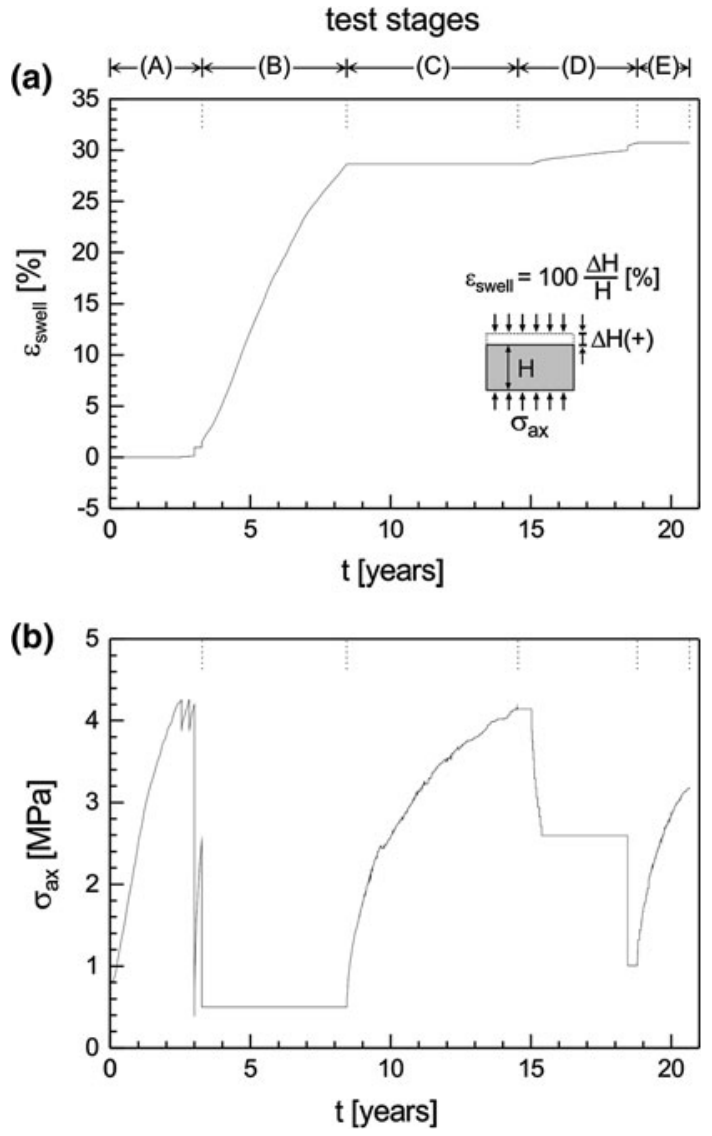

Fig. 2 Swelling test on sample "Abl. 2 B-10/166 T83.50-83.70 m" from the Freudenstein tunnel. a Strain versus time. b Stress versus time a non-linear extrapolation with the indirect least squares method (Späth 1973). This procedure allows one to estimate the asymptotic value, i.e. the supposed steady-state value for each loading step. So, for example, the extrapolation of the first loading steps in Fig. 2 with deformation constraint leads to swelling pressures higher than $10 \mathrm{MPa}$. The extrapolation of the first loading step with constant load $(\sigma=0.5 \mathrm{MPa})$ leads to a swelling strain of about $50 \%$

Figure 3 summarises the results of the test of Fig. 2 and nine other swelling tests in a swelling stress over swelling strain diagram and suggests that, in contrast to the semilogarithmic swelling law, the swelling strain is practically independent of the swelling stress over a wide stress range (up to about $4 \mathrm{MPa}$ ). A possible explanation is that crystal growth and specimen cracking occurs at stresses below a threshold value of about $4 \mathrm{MPa}$ (Pimentel 2007). Note that only very small strains develop at axial stresses above $4 \mathrm{MPa}$. The deformation constriction leads to the generation of swelling stress up to a value where gypsum crystal growth is thermodynamically no longer possible. At stresses below the threshold value of about $4 \mathrm{MPa}$, the crystallisation pressure that develops during gypsum crystal growth may locally exceed the tensile strength of the rock, leading to cracking and to larger deformations.

\subsection{Test Adit of the Freudenstein Tunnel}

The test adit U1 of the Freudenstein tunnel (Fig. 4a) was constructed with the aim of testing different support systems in swelling rock (Kovári et al. 1986). It is $120 \mathrm{~m}$ long

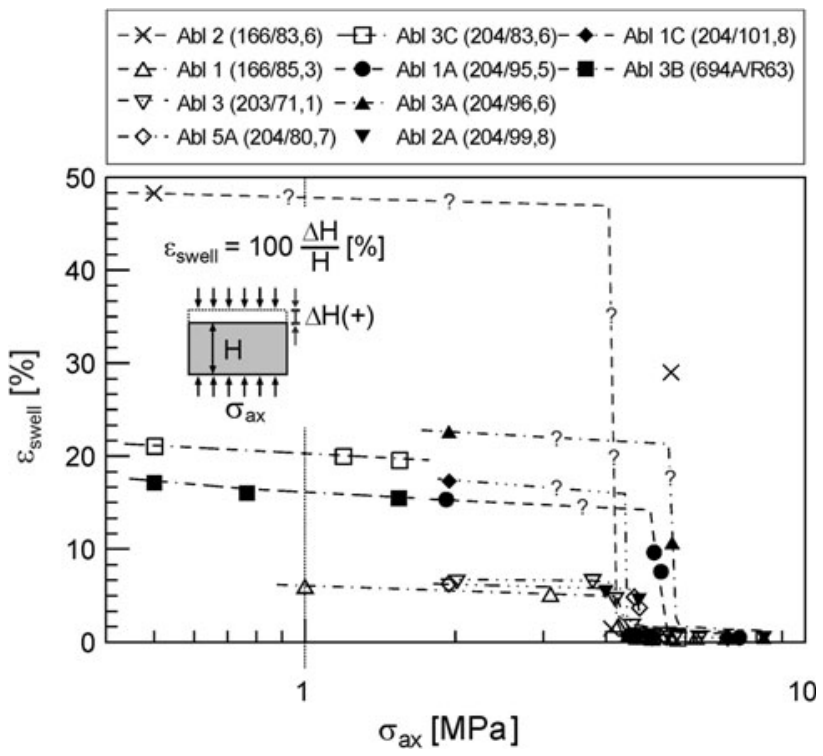

Fig. 3 Stress-strain values at the final state based on the extrapolation of ten experiments on samples from the Freudenstein tunnel (Pimentel 2007) 
and crosses (as does the railway tunnel) heavily swelling sulphatic claystones of the Gypsum Keuper formation. The overburden is about $65 \mathrm{~m}$. The adit was divided into 15 blocks. The invert of four of the blocks (blocks XI-XIV in Fig. 4a) was anchored by pre-stressed anchors driven $15 \mathrm{~m}$ into the sulphatic claystones (Fig. 4b). The chosen spacings and pre-stressing force of the anchors ensured that the support pressure exerted upon the floor was equal to 0.75 , $0.5,0.25$ and $0.1 \mathrm{MPa}$. Afterwards, the area beneath the tunnel floor was systematically watered, thus, accelerating the swelling process. Up to this point, the anchor loads were kept constant by repeatedly loosening the anchors. As the anchors were $15 \mathrm{~m}$ long (and the test adit was only $7 \mathrm{~m}$ wide), they reached beyond the swelling zone (this was confirmed by sliding micrometer measurements) (Fig. 4b). Figure 5a shows the time history of the measured floor heave for these four blocks (blocks XI-XIV in Fig. 4a). The monitoring results show that the support pressure clearly reduces floor heave. It was observed, however, that at a low support pressure of $0.1 \mathrm{MPa}$, the floor continued to heave at an almost constant rate 20 years after the test began, while the heave rate decreased at higher support pressures $(0.5$ and $0.75 \mathrm{MPa})$. As a consequence, the relationship between the support pressure and floor heave, which was initially strongly non-linear (thus, agreeing with the prediction of the semi-logarithmic law), changed to a practically straight line after 20 years (Fig. 5b). The heave over time curves of Fig. 5a do not enable a reliable extrapolation of the future floor heave. Therefore, the question remains unresolved as to whether and to what extent the support pressure reduces the final floor heave or only delays its development. Unfortunately, the monitoring results of the last 5 years have not been published.

It can be concluded that the semi-logarithmic swelling law has not been confirmed for sulphatic claystones, neither in the laboratory nor in the field. The interpretation of the laboratory results is uncertain due to the inherent difficulties of extrapolation and uncertainties relating to the effects of the complex test history. The field tests are incomplete, as a result of which even qualitative predictions of the relationship between the floor heave and the pressure are impossible to make.

\section{Design Considerations for the Test Apparatus}

\subsection{Brief Review of Existing Swelling Apparatuses}

Swelling tests are carried out mainly on undisturbed rock specimens. They can be grouped according to the imposed boundary conditions. The simplest test is the so-called "free swelling test", where the specimen is simply submerged in water and can deform freely (ISRM 1999). Usually, only the vertical deformation is recorded. The results provide information concerning the maximum swelling strain. One potential problem of this test is that the specimen can disaggregate during swelling, making an interpretation of the results problematic. This happens particularly to samples with a high clay content and low saturation.

The stress-strain behaviour of swelling rocks has been investigated under oedometric conditions (see below), triaxial conditions (Aristorenas 1992; Bellwald 1990; Barla 2008; Pimentel 1996) and true triaxial testing conditions (Pregl et al. 1980). Most swelling apparatuses used in engineering practice are designed for running oedometer tests. In such tests, the specimen is fitted with a stiff metallic ring, which constrains radial strain. Oedometer tests are, thus, practically one-dimensional expansion tests, with a clearly defined axial stress, but unknown radial stress.

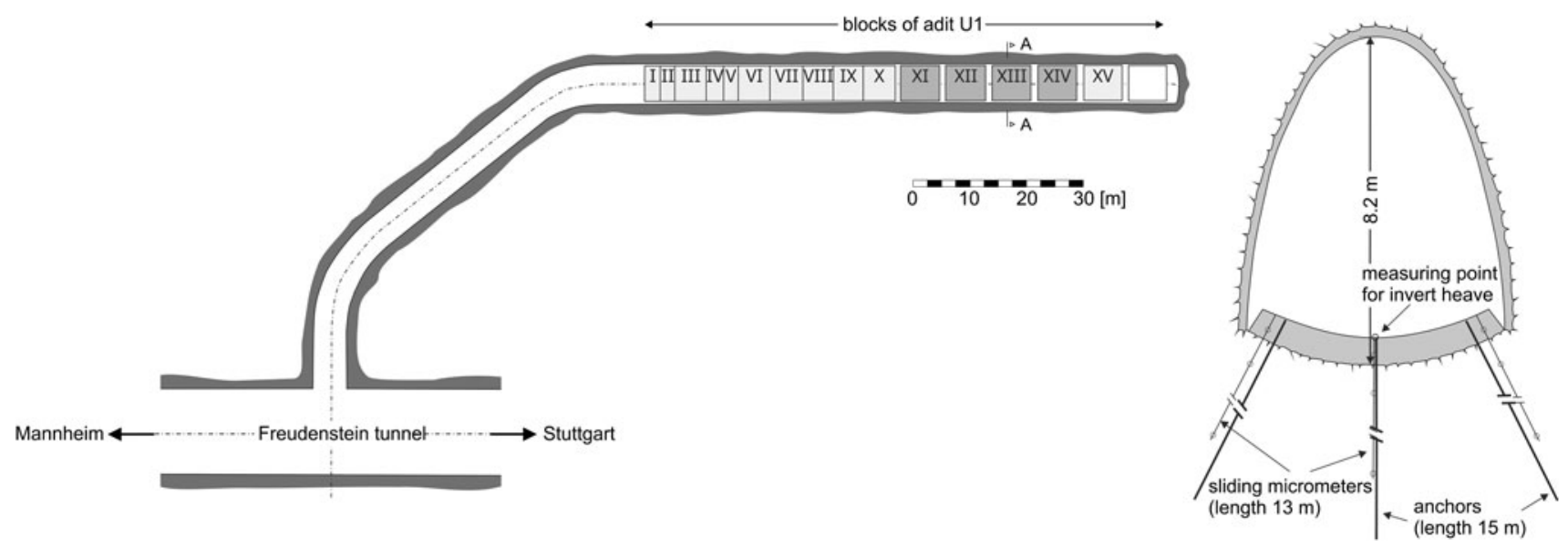

Fig. 4 Test adit U1 of the Freudenstein tunnel. a Plan view. b Cross section A-A (block XIII) (Kovári et al. 1986) 

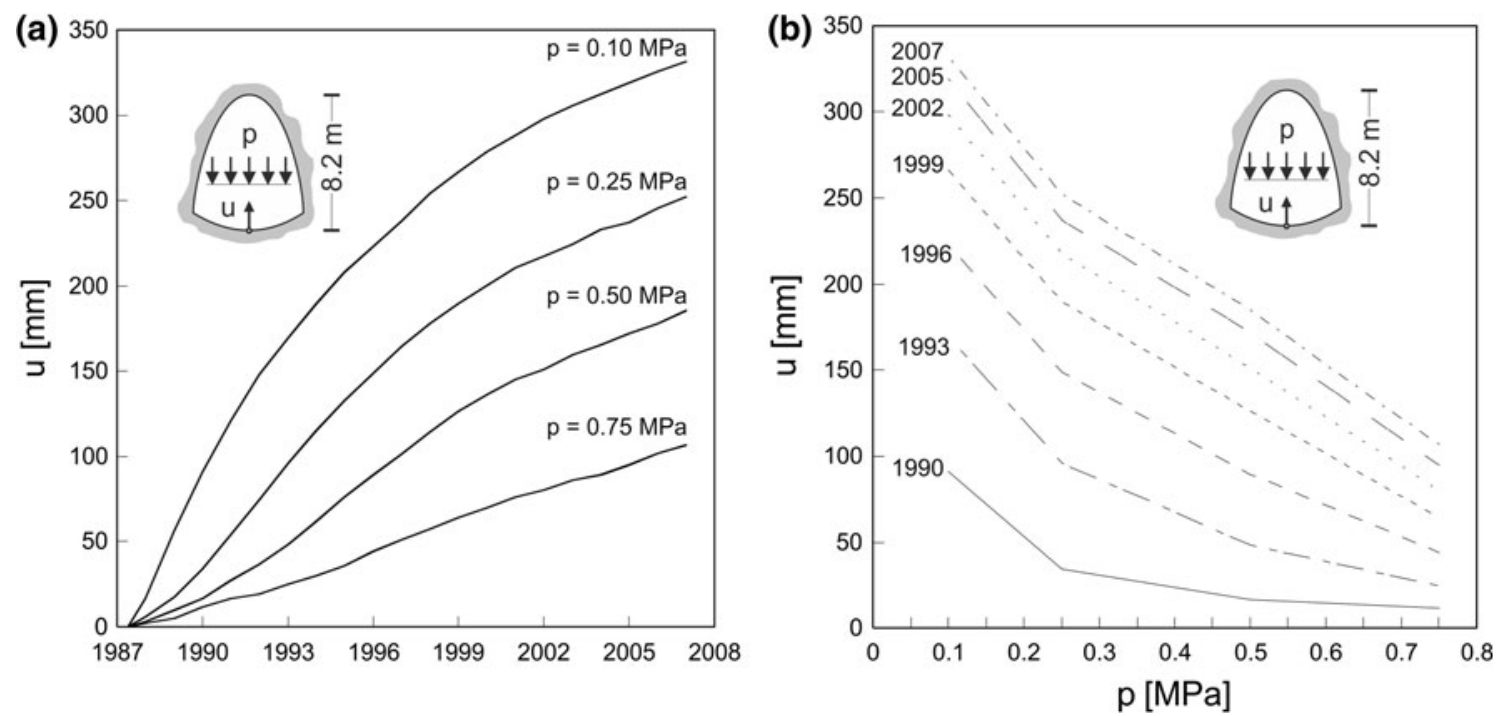

Fig. 5 Monitoring results from test adit U1 of the Freudenstein tunnel. a Time development of the invert heave at different support pressures (Wahlen 2009). b Dependency of invert heave on the support pressure at different times (data from Fig. 5a)

A swelling test for determining the maximum swelling pressure was proposed by Madsen (1976). The oedometer is placed in a water vessel and centred in a loading frame, which constrains the vertical deformation that develops after water is poured into the vessel. The vertical load is measured with a load cell. A main disadvantage of this apparatus is its relatively low stiffness. At high swelling pressures, the deformations of the reaction frame become relevant and must be compensated during testing.

The relationship between swelling stress and strain is usually determined by the multi-step test type, as initially proposed by Huder and Amberg (1970) and described by the ISRM (1999). Classic soil mechanics consolidation equipment is used. Analogue to the test described above, a unit comprising the specimen, ring and water vessel is placed in the loading frame. At the beginning of the test, the specimen is loaded, unloaded and reloaded up to a prescribed stress level at its natural water content. Subsequently, the swelling process is activated by pouring demineralised water into the vessel. The vertical deformation is recorded during the test, and the specimen is unloaded stepwise after achieving equilibrium. At each load stage, it is necessary to wait until equilibrium is achieved again. Measuring the deformations of each load stage at equilibrium makes it possible to determine the swelling law parameters, from which the maximum swelling pressure can be quantified by extrapolation. As most apparatuses are designed for testing clays, the nominal vertical loads are usually limited to a maximum of $10 \mathrm{kN}$. Therefore, the vertical stress that can be applied to an $80-\mathrm{mm}$-diameter specimen is lower than $2 \mathrm{MPa}$. A disadvantage of these apparatuses is that accidental unintentional jolting can falsify the measured values.
The swelling test apparatus developed at the University of Karlsruhe (Fecker 1980) includes a stiff, four-column frame (1 in Fig. 6), which can handle loads of up to $50 \mathrm{kN}$ and, thus, considerable swelling pressures. The tests can be run by prescribing either axial load or axial deformation. The latter can be controlled manually ( 2 in Fig. 6 ) with a spindle (3 in Fig. 6). The axial load is measured with an electric load cell (4 in Fig. 6) and the axial deformation with a dial gauge on the top of the spindle (5 in Fig. 6). The metallic ring was manufactured from brass and has a thickness of $1 \mathrm{~cm}$ (6 in Fig. 6). On both ends of the specimen ( 7 in Fig. 6), a porous plate (8 in Fig. 6) is placed, which allows uniform water drainage. In order to centre the porous plates, the specimen is $1 \mathrm{~mm}$ shorter than the cylinder. For submersing the sample in water, the system comprising of the specimen, ring and porous plates is placed in a vessel (9 in Fig. 6), which consists of a cylinder made of acrylic (PMMA) and is sealed at the bottom with a stainless steel plate. For a better load distribution, a head plate (10 in Fig. 6) is placed between the spindle and the upper porous plate. In order to compensate for potentially eccentric swelling deformations, a metallic sphere (11 in Fig. 6) is located between the spindle and the head plate.

This apparatus has been shown to work reliably over long periods while also offering the advantage of requiring less space and being lighter than the standard consolidation apparatus. It has, however, some disadvantages which are relevant for the purposes of the present research project:

- The difference between the ring height and the specimen height is too small to perform swelling tests with sulphatic claystones. At large strains, part of the 


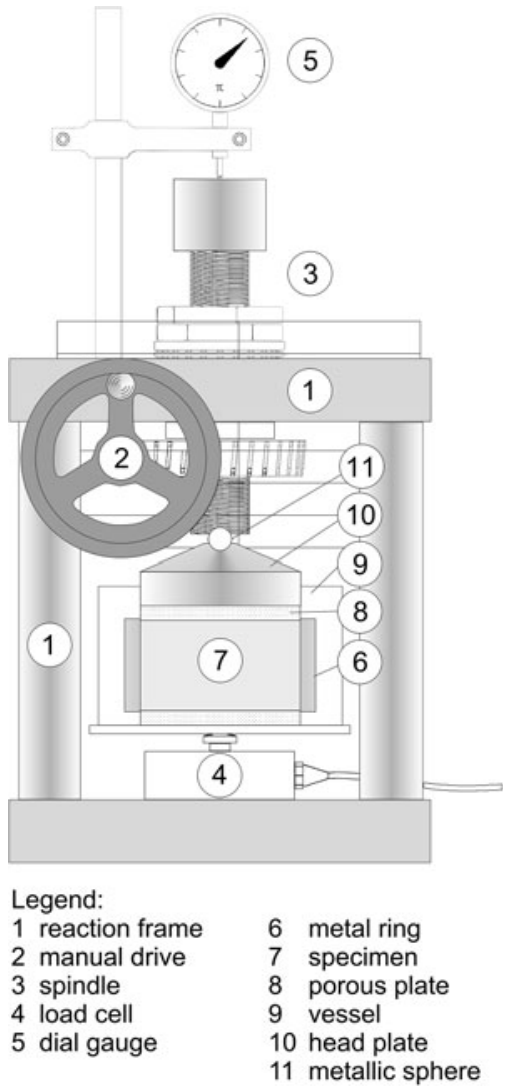

Fig. 6 Apparatus for swelling tests on samples from the Freudenstein tunnel (Pimentel 1996)



Fig. 7 Close-up of a swelling test after more than 20 years (specimen "Abl. 2-166/83" from the Freudenstein tunnel) specimen exits the ring, thus, violating the oedometric conditions (1 in Fig. 7).

- In long-term tests, the ring corrodes, as can be seen from the oxide colouring of the porous plate $(2$ in Fig. 7).

- The vessel can be covered with plastic foil to reduce evaporation (3 in Fig. 7). However, it is not sufficiently tight, so water must be added from time to time. A temporary reduction of the water level in the vessel leads to an increase in dissolved ions (that may be present due to leaching of the specimen) and, thus, affects the swelling process. An unplanned overfilling of the vessel can lead to a dilution of the ion concentration (4 in Fig. 7). All of this means that the convection and diffusion boundary conditions are uncertain.

- The load regulation, measurement and evaluation involve manual operations. This is very time consuming and error-prone, particularly for a large series of long-lasting tests.

- The deformation of the specimen is measured externally, i.e. the measurement also includes the deformation of the spindle, sphere, load distribution plate, load cell and frame columns. This is particularly relevant for deformation-controlled loading stages.

\subsection{Project Requirements for the Test Apparatus}

The current experimental programme aims to improve our knowledge about the stress dependency of swelling in claysulphate rocks and long-term laboratory tests are foreseen on undisturbed natural rock.

On account of the anticipated extremely long testing duration, only oedometer tests were considered as feasible concerning robustness, handling and long-term reliability. The effects of external factors or disturbances (such as load irregularities, temperature fluctuations, variations in the ionic concentration of the water in the vessel due to the oxidation of metallic parts or due to evaporation) should be minimised. All of the tests should run until completion of the swelling process under the prescribed boundary conditions. The apparatus should, therefore, remain reliable over a sufficiently long testing period, which means at least 10-15 years. Considering the long testing period, the work expended on test regulation, measurement and evaluation should be optimised.

The natural heterogeneity of rock specimens on a laboratory scale may cause some scatter in the results. Increasing the specimen size (to the scale of field tests) is impossible, because the duration of the swelling process, which amounts to several years even for small specimens, would be even longer in the case of large specimens (the 
duration of diffusion-controlled processes increases with the second power of the specimen size). A series of tests under the same boundary conditions (more specifically, under the same axial pressure) should, therefore, be carried out in order for them to have statistical significance and to make it possible to interpret the results in terms of the relationship between swelling strain and stress. In addition, the axial loads should cover the relevant stress range for tunnelling. Based on these considerations, we decided to run five series (with axial stresses between 0.5 and 2.0 MPa), each consisting of five tests. A total of 25 apparatuses, therefore, had to be constructed.

\subsection{Apparatus for Swelling Tests}

Based on the results of a review of existing equipment and bearing in mind the project requirements, we decided to improve the Karlsruhe apparatus by eliminating the deficiencies mentioned above (Sect. 3.1) and to design a new central loading device which will deal with the large number of tests and the long test duration.

Each apparatus consists of a four-column stiff reaction frame. The columns have a diameter of $4 \mathrm{~cm}$ (18 in Fig. 8). The rectangular endplates are of dimensions $27 \mathrm{~cm} \times$ $27 \mathrm{~cm} \times 4 \mathrm{~cm}$ (17 in Fig. 8). The specimen has a height of $4 \mathrm{~cm}$ and a diameter of $7 \mathrm{~cm}$ (1 in Fig. 8). It is placed in a metal cylinder of a special corrosion-resistant alloy (25\% $\mathrm{Ni}$ and $20 \% \mathrm{Cr}$ ) (2 in Fig. 8). The ring has a thickness of $13 \mathrm{~mm}$ and a height of $55 \mathrm{~mm}$, which allows for swelling deformations of $35 \%$. Porous plates of the same corrosionresistant alloy as the metal ring are placed at both ends of the specimen (3 in Fig. 8). The vessel holding the water for the submersion of the specimen also consists of a corrosion-resistant metallic plate and an acrylic cylinder ( 8 in Fig. 8). It is sealed hermetically with a cap (9 in Fig. 8). The cap contains a small opening (10 in Fig. 8) with a removable plug, which enables to fill the vessel with water at the start of the test and also makes it possible to collect water samples during the test for ionic concentration analysis. In the bottom and top plates (4 and 5 in Fig. 8), notches were drilled, producing a more uniform watering of the specimen. In order to compensate for potentially eccentric swelling deformations, spherical plates with same radius as the specimen are placed on the top and bottom (6 in Fig. 8). The deformation of the specimen is measured from close up with two digital dial gauges (14 in Fig. 8), which are fixed to the spherical plate on the top (13 in Fig. 8), measuring the displacement relative to a bolt (11 in Fig. 8). The latter is fixed to the spherical plate on the bottom (12 in Fig. 8). The load is applied by a jack (15 in Fig. 8).

The oil pressure for the jacks is generated with a central pressure generator (Fig. 9), which is controlled by weights.

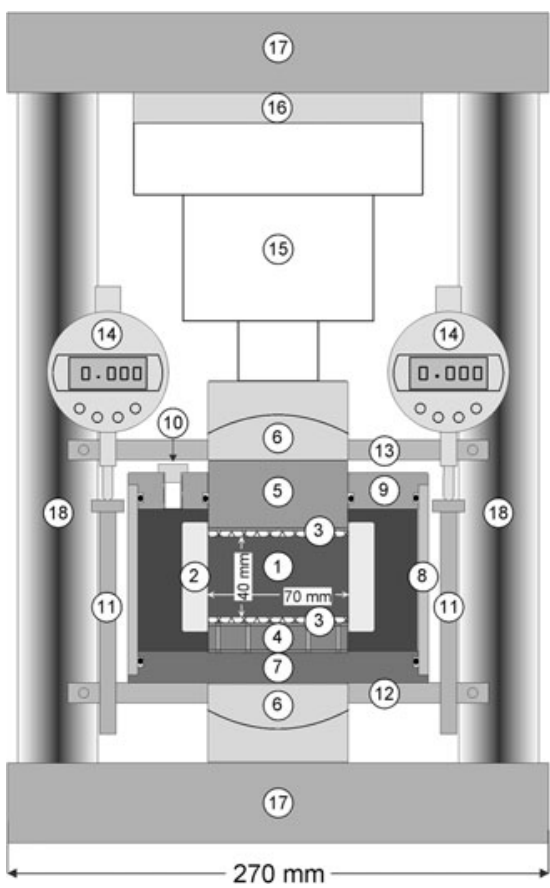

Legend:

1 specimen

2 metal ring

3 porous plate

4 plate with notches

5 plate with notches

6 calotte

7 bottom plate of vessel

8 cylinder of vessel

9 cap of vessel

10 removable plug

11 bolt

12 bolt fastener

13 dial gauge fastener

14 digital dial gauge

15 jack cylinder

16 plate for fixing the cylinder

17 endplate of reaction frame

18 column of reaction frame

Fig. 8 New swelling test apparatus (Pimentel and Anagnostou 2010)

The weights apply a force with a leverage ratio of 5:1 to a central jack generating the oil pressure for the entire equipment. For all test series (with the exception of the one with the highest pressure), a pressure reducer consisting of two jacks with different cross sections is placed between the central pressure generator and the individual reaction frames (Fig. 9). The oil pressure, and, thus, the axial load in the different test series as well, are proportional to the ratio of the cross sections of the pressure reducers. Since the swelling strains (and, consequently, the displacement of the jacks) occur very slowly, the conditions prevailing in the hydraulic circuit are uniform. The system is not

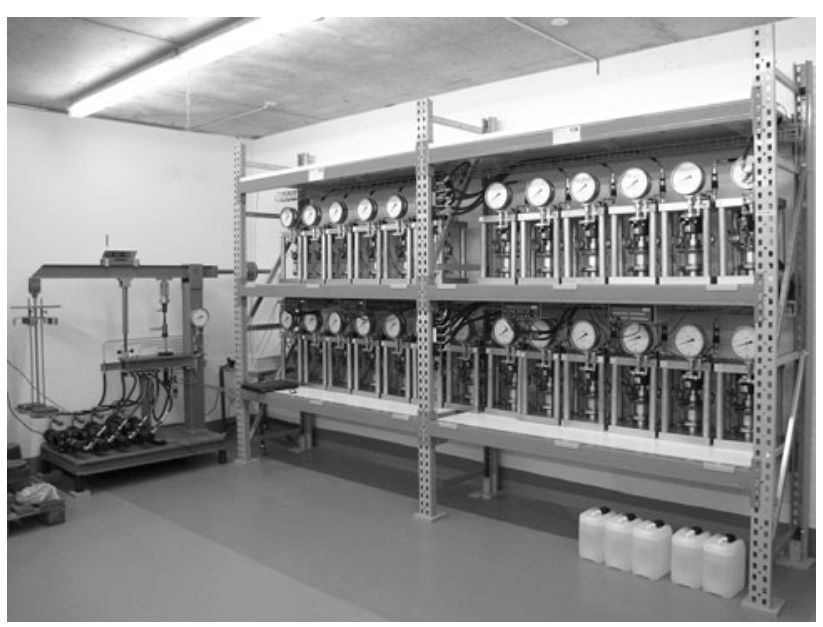

Fig. 9 Overview of the equipment 
sensitive to oil leakages, i.e. the oedometer axial loads remain constant. This loading system does not need any calibration and guarantees high accuracy.

Valves are placed on each jack in the system as well as in the central oil pipe of each test series (Fig. 10). In this way, a single apparatus (e.g. 1 in Fig. 10) or an entire series (e.g. 2 in Fig. 10) can be decoupled from the central load generation device without affecting the other tests. This allows us to change the position of the jacks of the pressure generator or of the pressure reducers at a later stage, to refill the system in the unexpected case of significant oil leakage, as well as to replace some specimens, without affecting the other tests.

As indicated above, the apparatuses were designed primarily for running load-controlled swelling tests. The apparatuses may, therefore, also be used for running other long-term tests under constant load, such as creep tests or chemo-mechanics tests (e.g. for concrete swelling and degradation).

On the other hand, deformation-controlled tests are also possible. For this purpose, one must simply install an oil pressure transducer (for remotely recording the swelling pressure) and close the valve at the respective jack cylinder (1 in Fig. 10), thus, suppressing oil circulation and oil volume changes. Since the reaction frame, as well as other components such as plates and spherical plates, is rigid, the deformation of the apparatus occurring due to the increasing axial load will be small.
The two digital dial gauges for measuring swelling strains are connected via a multiplexer to a data logger, which is programmed to record the measurements and the time automatically once per hour. It is always possible to change the measuring frequency. The electricity supply for the data logger is conventional (public electricity service). In order to overcome eventual power outages, the electricity supply is connected to a capacitor and an accumulator, providing energy for up to 1 day. The recorded data can be saved periodically on a laptop (e.g. every week). With this system, little work is required for control, measuring and evaluation. In order to minimise temperature effects, the equipment was installed in an air-conditioned room with a temperature of $21{ }^{\circ} \mathrm{C} \pm 0.5{ }^{\circ} \mathrm{C}$.

\section{Test Material and Specimen Preparation}

The test material was obtained from the Chienberg tunnel, a 2.3-km-long tunnel near the town of Sissach in Northwestern Switzerland, about $25 \mathrm{~km}$ southeast from Basel (Fig. 11). The tunnel crosses the sulphatic claystones of the Gypsum Keuper. Close to the portal areas, where the depth of cover is small, the upper boundary of the Gypsum Keuper is about at the elevation of the tunnel (Figs. 12 and 13). Due to the anticipated heavy swelling behaviour of the Gypsum Keuper, the planned cross section of the tunnel was circular (6-m excavation radius) and the cast-in-situ

Fig. 10 Hydraulic circuit of the equipment

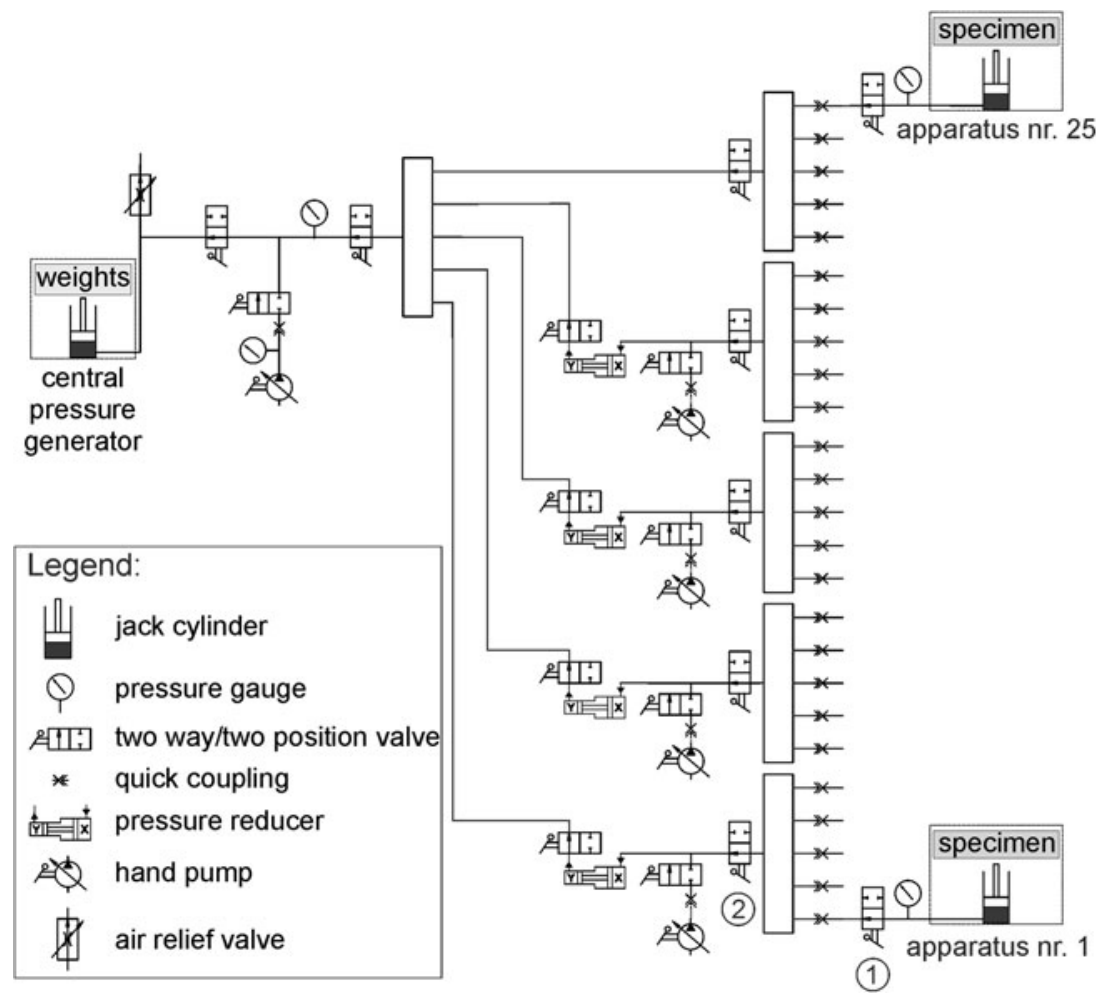


concrete inner lining was $0.7-1.1 \mathrm{~m}$ thick (Chiaverio and Thut 2010). About 4 months after the construction of the inner lining, heaves of the entire tunnel lining and of the surface were observed along a 90-m-long stretch, with an overburden of about $25-30 \mathrm{~m}$ (referred to as "Heave Section 1" in Fig. 12). A short time later, heaves were also observed in a second stretch, with a length of $140 \mathrm{~m}$ and an overburden of 40-50 m ("Heave Section 2" in Fig. 12). Both swelling areas are located close to the west portal area of the tunnel. The anhydrite-gypsum interface (referred to as the "anhydrite level" in Fig. 12) was identified at the level of the tunnel invert. Due to the inadmissible heaves and deformations, which developed at a practically constant rate of $0.6 \mathrm{~mm}$ per month at the crown and about $1 \mathrm{~mm}$ per month at the bottom of the sidewalls, the decision was taken to demolish the lower part of the installed final lining and to replace it with a new lining based on a completely new structural concept (Kovári and Chiaverio 2007). The new concept consists of an open space beneath the carriageway, which can be accessed at any time and allows floor heave to take place without impairing the serviceability of the tunnel. In order to reduce the floor heave rate and avoid frequent re-profiling work, pre-stressed anchors exerting a pressure of 0.5 MPa were installed in the tunnel invert. Both the anchor force and the swelling pressure acting above the lining foundation are controlled by specially developed yielding elements (Fig. 14). These measures were also applied in an area of potential swelling close to the eastern portal (Fig. 13).

The test material for the swelling tests was obtained during the re-construction work described above. For this purpose, six cored boreholes were drilled from the new invert of the tunnel extension. The boreholes were located in what was an anhydritic region according to the geological documentation (later, we found out, however, that anhydrite was completely absent from one borehole) and close to monitoring sections, where sliding micrometers

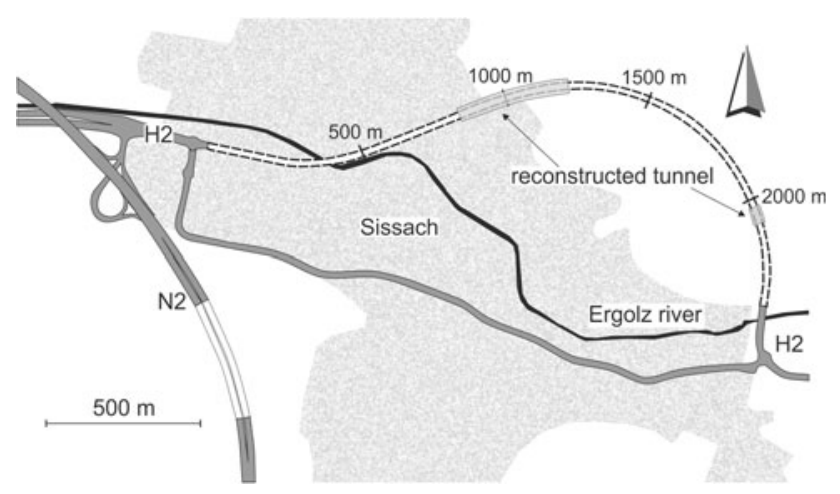

Fig. 11 Horizontal alignment of the Chienberg tunnel (after Aegerter \& Bosshardt AG and Gruner AG 2005) and anchor bolts were placed for monitoring deformations in the rock mass and in the lining. This will eventually allow the correlation of laboratory and field measurements. Four of the boreholes were located in the western zone (chainage 845, 935, 1,194.5 and 1,197 m, Fig. 12), while the other two boreholes were drilled in the eastern zone (chainage 2,040 and 2,042 m, Fig. 13). From each borehole, all core pieces longer than $70 \mathrm{~mm}$ were taken (shorter pieces are not adequate for preparing specimens for swelling tests). In general, core recovery from the boreholes in the western zone was considerably less successful than from the other two boreholes. Only eight core pieces, with a maximum length of $15 \mathrm{~cm}$, could be taken from the borehole at chainage $1,194.5 \mathrm{~m}$. Care was taken to disturb the samples as little as possible during transport and preparation (e.g. to avoid drying, shaking etc.).

The samples selected for running the tests originate from the western zone (boreholes TM 845 and TM 935) and from the eastern zone (boreholes TM 2040 and TM 2042). The criteria for this selection were: (1) that the samples should stem from the rock layers beneath the anhydritegypsum interface (Figs. 12, 13) and (2) that enough core pieces of good quality should be available for running tests at different axial loads with more or less the same material.

Besides avoiding mechanical specimen disturbance, a main requirement for specimen preparation was to obtain specimens with a well-defined geometry. In order to ensure oedometric conditions right from the start of the test, accurate fitting of the specimen into the ring was necessary. For this purpose, the specimens were trimmed slowly on a lathe with a rotation speed of $50 \mathrm{revs} / \mathrm{min}$ (Fig. 15). Afterwards, the specimen end surfaces were cut perpendicular to the specimen axis by an electronically controlled and air-flushed diamond band saw. The height of each specimen is $40 \mathrm{~mm}$.

The specimens were weighed and photographed immediately after cutting (Fig. 16): at the macroscopic scale, structural differences were instantly apparent between the specimens from boreholes TM 935 and TM 2040. In the first case, the anhydrite is more uniformly distributed in irregular layers (1 in Fig. 16), while in the second case, the anhydrite particles are nodular, with sizes within the range of $\mu \mathrm{m}$ to a few cm (2 in Fig. 16). Specimen TM 935/3/1/1 contains a horizontal strip of anhydrite at the top, with a maximum thickness of about $0.5 \mathrm{~cm}$ (3 in Fig. 16). Specimen TM 2040/10/3 contains a strip of anhydrite at the bottom, and it is more or less vertically oriented (4 in Fig. 16), while a diagonal thin anhydrite vein can be observed in specimen TM 2040/10/2 (5 in Fig. 16). These structures, i.e. layers, nodules and sporadic stripes or veins, are typical for anhydrite in natural rocks (Langbein et al. 1982). It should be pointed out that the distance between both sets of boreholes is less than $1 \mathrm{~km}$. 



Heave Section 1

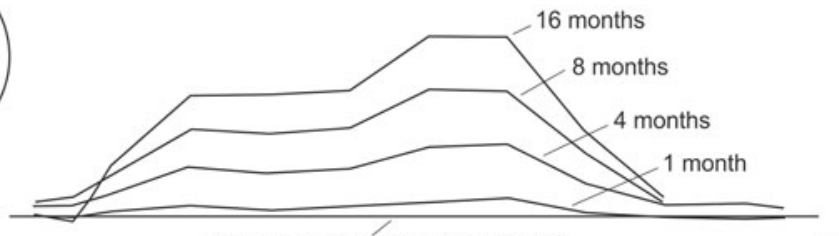

reference measurement (09.11.03)

Heave Section 2

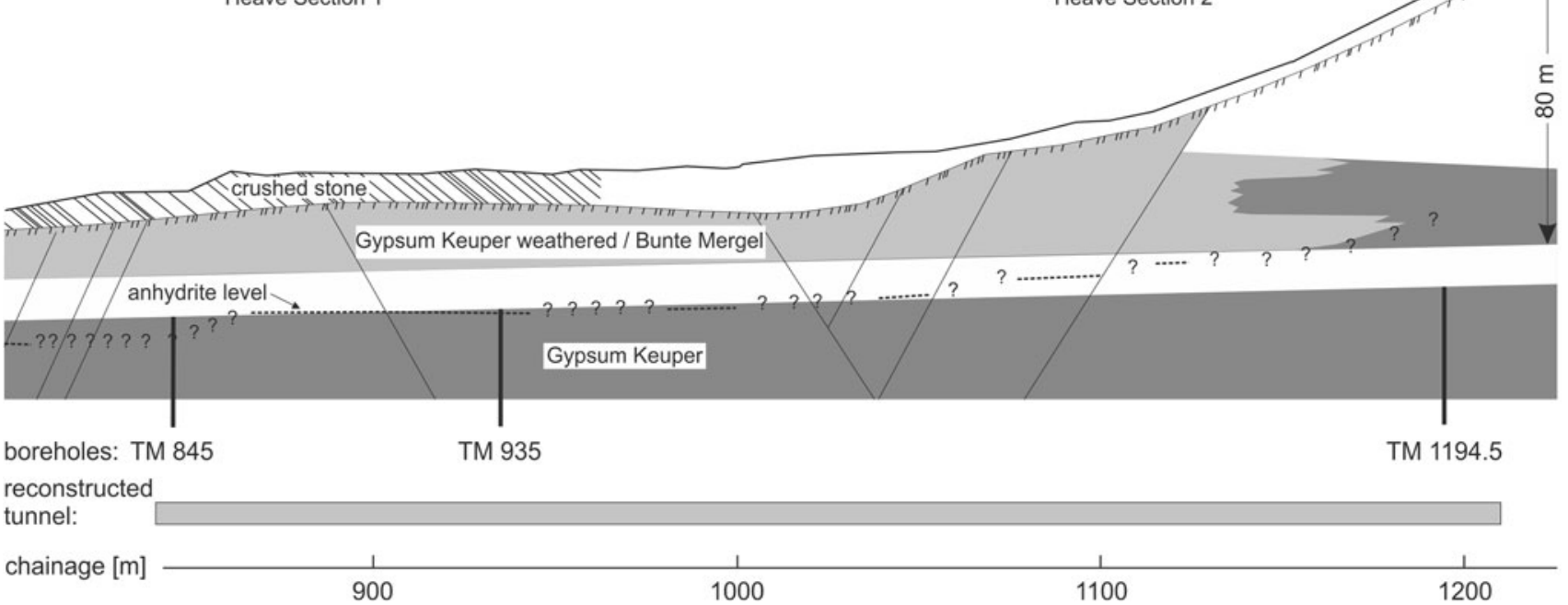

Fig. 12 Geological profile in the western portal area with location of the boreholes for swelling samples and measured heave along the tunnel (geological information after Aegerter \& Bosshardt AG and

Gruner AG 2005 and source data of the plotted measured heave from Aegerter \& Bosshardt and Gruner AG 2006)

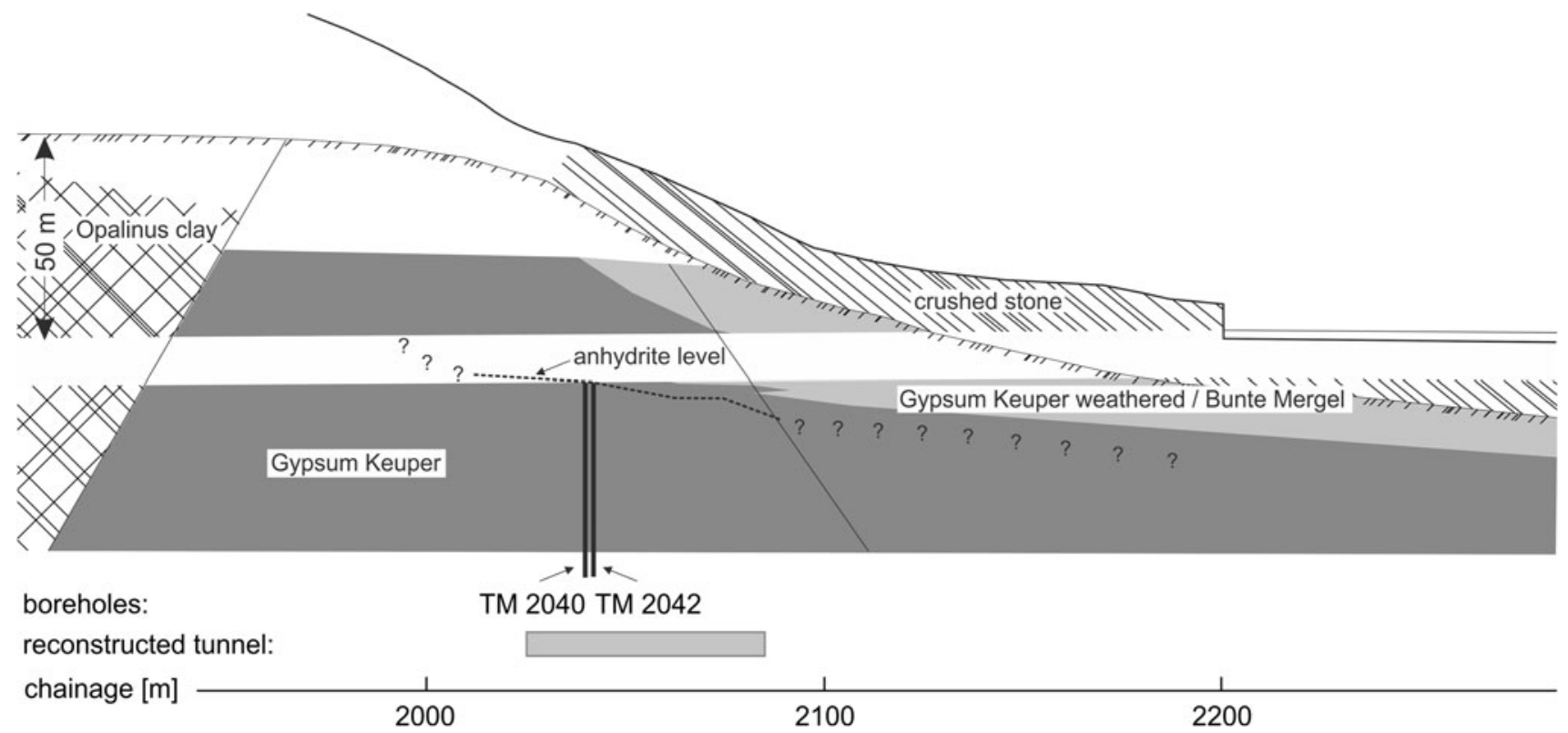

Fig. 13 Geological profile in the eastern portal area with location of the boreholes for swelling samples (geological information after Aegerter \& Bosshardt AG and Gruner AG 2005) 




Fig. 14 Tunnel profile after re-construction work (Kovári and Chiaverio 2007)



Fig. 15 Specimen preparation with a lathe

\section{First Results}

After assembling the specimens in the reaction frames (Fig. 8), the prescribed loads (corresponding to axial

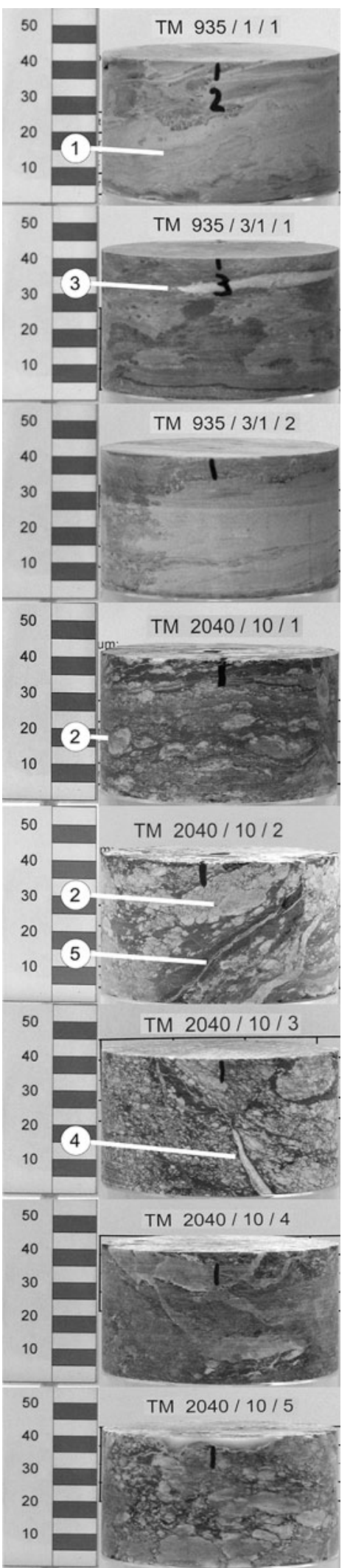

Fig. 16 Specimens after preparation 
Table 1 Mineralogical composition of the samples (mass \%)

\begin{tabular}{llllc}
\hline & TM 845 & TM 935 & TM 2040 & TM 2042 \\
\hline Gypsum & $38.9-84.1$ & $0.4-4.1$ & $11.0-20.7$ & 9.8 \\
Bassanite & $2.0-12.0$ & 0 & $0-1.1$ & 0 \\
Anhydrite & $0-1.8$ & $52.8-84.4$ & $31.2-80.2$ & 63.2 \\
Quartz & $1.2-3.4$ & $1.8-4.4$ & $1.1-12.3$ & 7.2 \\
K-feldspar & $1.1-2.3$ & $1.3-2.4$ & $1.5-5.8$ & 1.8 \\
Dolomite & $1.6-41.1$ & $0-3.2$ & $0-12.4$ & 0 \\
Magnesite & $0-3.8$ & $6.2-25.5$ & $0.6-11.5$ & 4.8 \\
Muscovite & $0-2.1$ & $1.7-3.8$ & $1.3-5.4$ & 3.0 \\
Chlorite & $0-0.8$ & $1.0-1.6$ & $0.7-6.0$ & 2.8 \\
Illite/smectite & 0 & $0-5.3$ & $2.3-12.2$ & 7.4 \\
mixed layer & & & & \\
\hline
\end{tabular}

pressures of 0.5-2 MPa, Sect. 3.2) were applied and the specimens were left until settlements were no longer registered. A reference measurement was done and demineralised water was added in order to start the experiments. The deformations were recorded every $10 \mathrm{~min}$ during the first 2 days and later every hour. Some specimens showed small settlements during the first few hours. This deformation was not taken into account in the evaluation of the swelling strain. Some specimens showed no swelling or even small settlements after several months. In order to identify the reason for this unexpected behaviour, the mineralogical composition of the remaining pieces of tested cores was determined with X-ray diffractometry. Table 1 shows the mass fraction ranges of the different minerals. The specimens from borehole TM 845 show a high content of gypsum and practically no anhydrite or clay minerals with swelling potential. This result correlates well with the absence of swelling strains (Fig. 17). The other samples showed a medium to high anhydrite content and some clay minerals. The findings from borehole TM 845 (no anhydrite, no swelling) were very surprising because this borehole should be located completely beneath the anhydrite level according to the geological information available before testing.

The specimen from borehole TM 935/3/1/1 (with $0.5 \mathrm{MPa}$ axial loading) shows the highest swelling rate (Fig. 18). The rate is nearly constant and amounts to about $6 \%$ per year. The swelling rates of the other specimens (with higher pressures of 0.8 and $2.0 \mathrm{MPa}$ ) are about one order of magnitude lower. It must be pointed out that the specimens loaded with 0.5 and $0.8 \mathrm{MPa}$ were obtained from the same core piece. The specimens from borehole TM 2040 (results in Fig. 19) were also obtained from the same core piece. After 10 months, they show a nearly constant swelling rate of less than $0.24 \%$ per year. The specimen with the lowest applied load $(0.5 \mathrm{MPa})$ shows the highest swelling strain, while the specimens with higher

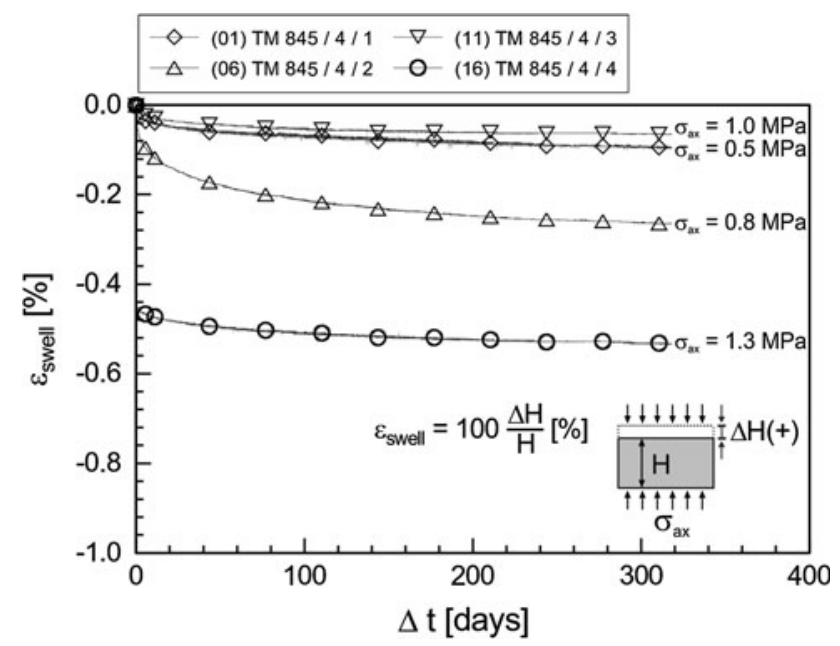

Fig. 17 Results of the swelling tests on specimens from borehole TM $845 / 4$

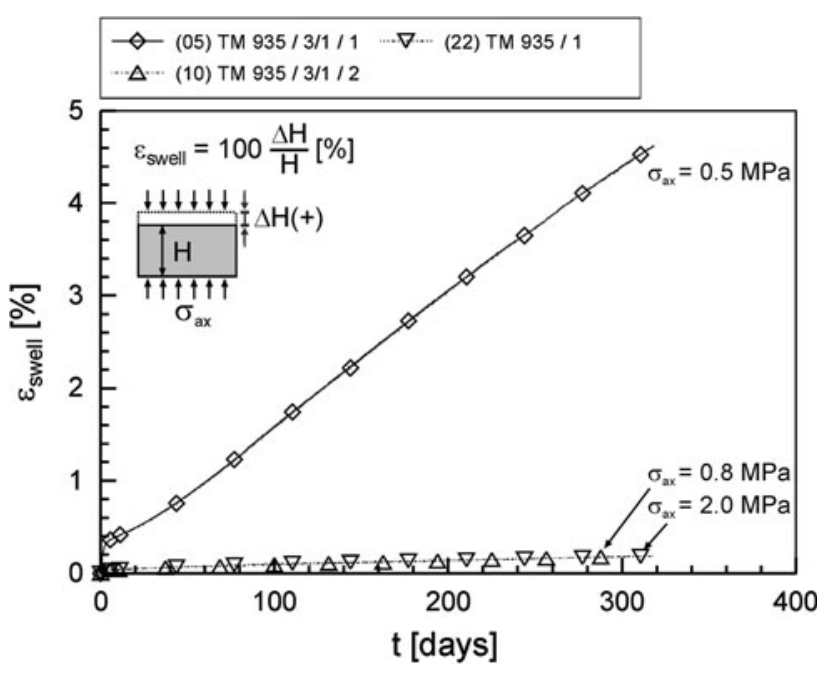

Fig. 18 Results of the swelling tests on specimens from borehole TM 935

applied loads (1.3 and 2.0 MPa) show the lowest swelling strains. The specimens obtained from other core pieces of borehole TM 2040 and borehole TM 2042 show lower swelling rates. It is still too early to make any statement about the possible final state of each experiment.

\section{Conclusions}

Although the swelling phenomena have been recognised in tunnelling for the past 150 years, important questions remain unanswered. One question, which is particularly important with respect to tunnel support design, concerns the swelling law. The validity of the semi-logarithmic swelling law, which is used for describing the swelling behaviour of claystones, is uncertain for sulphatic 


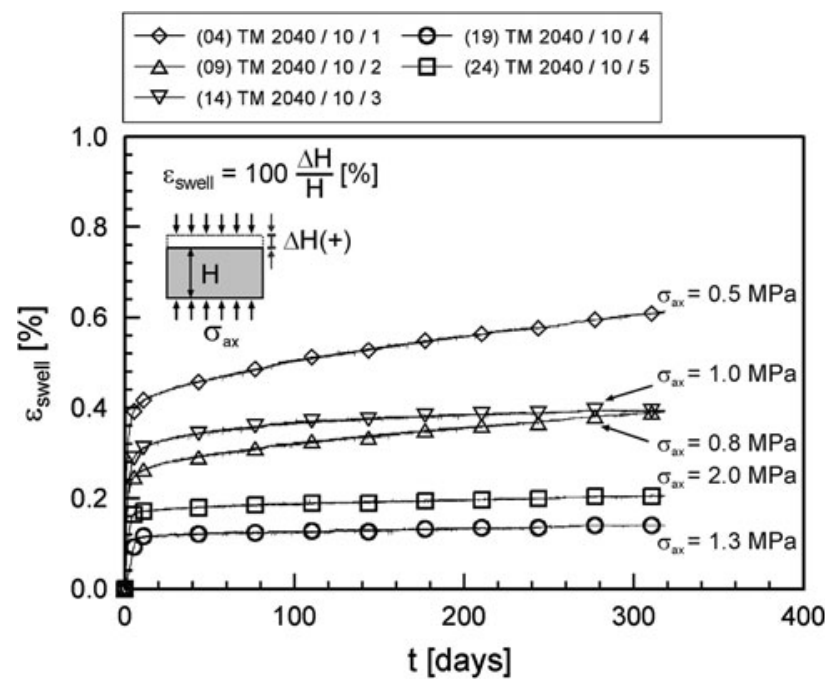

Fig. 19 Results of the swelling tests on specimens from borehole TM 2040/10

claystones. Based on the sparse data available from longterm laboratory and field swelling tests, it is not possible to make a definite statement. A new apparatus for swelling tests has been developed, which improves existing designs with the aim of running a series of long-term oedometer tests under constant loads with high reliability and minimum demands on personnel and at moderate equipment costs. A series of swelling tests on sulphatic claystones from the Chienberg tunnel has been started.

Acknowledgments The authors appreciate the financial aid and support for this project from FEDRO (the Swiss Federal Road Office), SBB (the Swiss Federal Railways) and the Authorities of the Canton Basel Country.

\section{References}

Aegerter \& Bosshardt AG, Gruner AG (2005) Chienbergtunnel Überwachung, Plan 5535/9926 h. Oberfläche/Tunnel, Tm 400-2294 (Portal Ost), Situation, Längenprofil, Stand 18.11.2005, erstattet an Bau- und Umweltschutzdirektion Kanton Basel-Landschaft

Aegerter \& Bosshardt AG, Gruner AG (2006) Chienbergtunnel Überwachung, Statusbericht Stand März 2006, erstattet an Bauund Umweltschutzdirektion Kanton Basel-Landschaft

Alonso E, Gens A, Berdugo I, Romero E (2005) Expansive behaviour of a sulphated clay in a railway tunnel. In: Proceedings of the 16th international conference on soil mechanics and geotechnical engineering, Osaka, Japan, September 2005, pp 1583-1586

Amstad C, Kovári K (2001) Untertagbau in quellfähigem Fels. Forschungsauftrag 52/94 auf Antrag des Bundesamtes für Strassen (ASTRA)

Anagnostou G (2007) Design uncertainties in tunnelling through anhydritic swelling rocks. Felsbau Rock Soil Eng 25(4):48-54

Anagnostou G, Pimentel E, Serafeimidis K (2010) Swelling of sulphatic claystones-some fundamental questions and their practical relevance. Geomech Tunnelling 3(5):567-572
Aristorenas GV (1992) Time-dependent behavior of tunnels excavated in shale. Doctoral thesis, Massachusetts Institute of Technology, Boston, Massachusetts

Barla M (2008) Numerical simulation of the swelling behaviour around tunnels based on special triaxial tests. Tunn Undergr Space Technol 23:508-521

Bellwald P (1990) A contribution to the design of tunnels in argillaceous rock. Doctoral thesis, Massachusetts Institute of Technology, Boston, Massachusetts

Chiaverio F, Thut A (2010) Rehabilitation using yielding elements of the section in Keuper sediments affected by heave. Geomech Tunnelling 3(5):573-582

Einstein HH (1996) Tunnelling in difficult ground-swelling behaviour and identification of swelling rocks. Rock Mech Rock Eng 29(3):113-124

Fecker E (1980) Quantitative Zusammenhänge zwischen der mineralogischen Umwandlung von Anhydrit in Gips und der Volumenvergrösserung im Tunnelbau. Forschungsbericht Nr. 15.062 R77E des Lehrstuhls für Felsmechanik der Universität (TH) Fridericiana zu Karlsruhe an die Bundesrepublik Deutschland vertreten durch den BMV

Flückiger A, Madsen FT, Nüesch R (1994) Anhydritquellung. Jahresbericht 1994, internal report of the Clay Mineralogy Laboratory of the ETH Zurich

Grob H (1972) Schwelldruck im Belchentunnel. In: Proceedings of the international symposium on underground construction, Lucerne, Switzerland, September 1972, pp 99-119

Huder J, Amberg G (1970) Quellung in Mergel, Opalinuston und Anhydrit. Schweizerische Bauzeitung, 88 Jahrgang Heft 43:975-980

International Society for Rock Mechanics (ISRM) (1994) Comments and recommendations on design and analysis procedures for structures in argillaceous swelling rock. Int J Rock Mech Min Sci Geomech Abstr 31:535-546

International Society for Rock Mechanics (ISRM) (1999) Suggested methods for laboratory testing of swelling rocks. Int J Rock Mech Min Sci 36:291-306

Kirschke D (1987) Laboratory and in situ swelling test for the Freudenstein tunnel. In: Proceedings of the 6th international congress on rock mechanics, Montreal, Canada, August/September 1987, vol 3, pp 1492-1496

Ko SC, Nüesch R, Madsen FT (1997) Tonmineralien und Sulfatgesteine als Ursachen für druckhaftes Verhalten von Gesteinen. Forschungsprojekt Quellverhalten der Juragesteine

Kovári K, Amstad Ch, Anagnostou G (1988) Design/construction methods-tunnelling in swelling rocks. In: Cundall PA et al. (eds) Proceedings of the 29th U.S. Symposium. Key questions in rock mechanics, Minnesota, Minneapolis, June 1988, pp 17-32

Kovári K, Fecker E, Amstad Ch (1986) Freudensteintunnel Versuchsstrecke U1-Mess- und Untersuchungsprogramm. Bericht des IBETH, Fels- und Untertagbau ETH Zürich und der Ges. für Baugeologie und-messtechnik mbH erstattet an die Deutsche Bundesbahn, NBS Mannheim Stuttgart, August 1986

Kovári K, Chiaverio F (2007) Modulares Knautschsystem für Tunnel in stark quellfähigem Gebirge. STUVA TAGUNG'07, Forschung + Praxis 42, bau verlag, Gütersloh, pp 195-200

Langbein R, Peter H, Schwahn HJ (1982) Karbonat- und Sulfatgesteine. Deutscher Verlag für Grundstoffindustrie, Leipzig

Madsen FT (1976) Quelldruckmessung an Tongesteinen und Berechnung des Quelldrucks nach der DLVO-Theorie. Mitteilungen des Institutes für Grundbau und Bodenmechanik der ETH Zürich. Nr. 108, pp 1-65

Madsen FT, Müller-Vonmoos M (1989) The swelling behaviour of clays. Appl Clay Sci 4:143-156

Madsen FT, Nüesch R (1990) Langzeitquellverhalten von Tongesteinen und tonigen Sulfatgesteinen: Mitteilungen des Institutes für Grundbau und Bodenmechanik der ETH Zürich, Nr. 140 
Nüesch R, Steiner W, Madsen FT (1995) Long time swelling of anhydritic rocks: mineralogical and microstructural evaluation. In: Proceedings of the 8th international congress on rock mechanics, Tokyo, Japan, September 1995, pp 133-138

Pregl O, Fuchs M, Müller H, Petschl G, Riedmüller G, Schwaighofer B (1980) Dreiaxiale Schwellversuche an Tongesteinen. In: Geotechnik 3, Heft 1

Pimentel E (1996) Quellverhalten von diagenetisch verfestigtem Tonstein. Veröffentlichungen des Institutes für Bodenmechanik und Felsmechanik der Universität Karlsruhe. Heft 139

Pimentel E (2003a) Swelling behaviour of sedimentary rocks under consideration of micromechanical aspects and its consequences on structure design. In: Proceedings of the international symposium on geotechnical measurements and modelling, Karlsruhe, Germany, September 2003, pp 367-374

Pimentel E (2003b) Langzeitschwellversuche an Probenmaterial aus dem Freudensteintunnel. Zwischenbericht für den Zeitraum 0.1.01.2001-01.10.2003. Bericht des Lehrstuhls der Universität Karlsruhe, erstattet an die DB Projekte Süd GmbH
Pimentel E (2007) A laboratory testing technique and a model for the swelling behavior of anhydritic rock. In: Proceedings of the 11th international congress on rock mechanics of the ISRM, Lisbon, Portugal, July 2007, vol 1, pp 14-146

Pimentel E, Anagnostou G (2010) Langzeitquellversuche an anhydritführenden Gesteinen. Forschungsauftrag FGU 2006/001 auf Antrag des Bundesamtes für Strassen (ASTRA), FB 1318

Späth H (1973) Algorithmen für elementare Ausgleichsmodelle. R. Oldenbourg Verlag GmbH, München

van Olphen H (1963) An introduction to clay colloid chemistry. Interscience Publishers, New York

Vögtli B, Jordan P (1996) Quelldruckentwicklung in Ton-und Sulfatgesteinen. Schweizer Ingenieur-und Architektenverein $18: 350-352$

Wahlen R (2009) Validierung eines Berechnungsverfahrens für Tunnelbauwerke in quellfähigem Gebirge. WBI-Print 17. VGE Verlag GmbH 